\title{
ATUALIZAÇÃO NA ASSISTÊNCIA PRÉ-NATAL
}

Victor Hugo de Melo, Suzana Maria Pires do Rio, Wanderley Marques Bernardo

\section{TEMA ABORDADO}

Especialidade de abrangência: Ginecologia e Obstetrícia.

Diretriz a ser consultada: Assistência pré-natal - parte II

Cenários e questónes clínicas

1- A redução de cãibras na gravidez é obtida com a suplementação de:

a - Cloreto de sódio

b - Cálcio

c - Vitaminas

d - Sais minerais

e - Citrato de magnésio

2 - Entre os antieméticos abaixo, qual não apresenta evidências na redução das náuseas e vômitos no início da gravidez?

a - Anti-histamínicos

b - Doxilamina com piridoxina

c - Metoclopramida

d - Vitamina B6

e - Gengibre

3 - A redução no número tradicional de consultas de pré-natal está associada a:

a - Resultados adversos maternos ou perinatais

b - Infecção do trato urinário

c - Insatisfação da gestante

d - Mortalidade materna

e - Baixo peso ao nascer

4 - Em relação ao rastreamento em gestantes assintomáticas para vaginose bacteriana é correto:

a - Reduz o parto pré-termo

b - Reduz o risco de rotura prematura de membranas

c - É recomendado para todas as gestantes assintomáticas

d - Deve ser considerado em mulheres com história prévia de parto pré-termo

e - Reduz o risco de bacteriúria assintomática

5 - Em relação à bacteriúria assintomática não é correto afirmar:

a - Deve ser rastreada entre 12 e 16 semanas de gestação

b - $\bigcirc$ tratamento não reduz a incidência de parto prematuro

c - O tratamento com antibiótico é efetivo

d - $\bigcirc$ tratamento reduz a incidência de pielonefrite

e - $\bigcirc$ tratamento reduz a incidência de baixo peso ao nascer

\section{Respostas do Cenário Clínico: Atualização, na assistênCia pré-natal (Parte I), baseada em evidência E CENTRAda No Paciente. [Publicado na RAMB 2007; 53(6)]}

I. Os resultados falsos-positivos no diagnóstico precoce da gravidez através da dosagem da gonadotrofina coriônica humana (ßhCG) ocorrem na faixa de 2 a $25 \mathrm{mUI} / \mathrm{ml}$ (Alternativa B).

2. Com relação a situações gerais que produzem benefício ou risco à gravidez, podemos afirmar que a suplementação dietética com fibras vegetais ajuda a reduzir a constipação (Alternativa $A$ ).

3. As gestantes que trabalham têm maior risco de aborto espontâneo, quando têm antecedente de abortamento e trabalham mais de sete horas em pé (Alternativa C).

4. É incorreto afirmar em relação à ingestão de álcool durante a gestação, que recomenda-se a ingestão no máximo de até sete doses de álcool por semana (Alternativa D).

5. A atividade sexual no terceiro trimestre da gravidez não apresenta aumento de risco para o feto (Alternativa E). 